\title{
Süper Besin: Chia Tohumu (Salvia Hispanica L.)
}

\author{
Super Food: Chia Seed (Salvia Hispanica L.)
}

\section{Tuğba Özbek ${ }^{1}$, Neşe Şahin Yeşilçubuk ${ }^{2}$}

Geliş tarihi/Received: $10.04 .2017 \cdot$ Kabul tarihi/Accepted: 03.04.2018

\section{ÖZET}

Son ylllarda oldukça dikkat çeken bir tohum olan Chia tohumu (Salvia hispanica, L.), sağlık etkileri bilimsel çalışmalarca kanıtlanmış işlevsel besin bileşenlerinden diyet posası, n-3 yağ asidi, protein ve antioksidanları yüksek miktarda içeren bir besindir. Chia tohumu (100 g) 16 - 20 g protein, 30 - 38 g yağ, 18 - 20 g n-3 yağ asidi, 34 - 40 g toplam diyet posası içerir. Son yıllarda sağlıklı besin tüketimindeki eğilimler diyet posası ilaveli, n-3 yağ asitleri ve antioksidan içeriği zenginleştirilmiş ürünler yönündedir. Chia tohumu son yıllarda Dünya'da yaygın olarak görülen kanser, diyabet, obezite, kardiyovasküler hastalıkların önlenmesinde etkili olabilecek işlevsel besin bileşenlerini içermesi nedeniyle "süper besin" olarak da tanımlanmaktadır. Sağlık ve beslenme etkilerinin yanı sıra, Chia tohumu, su ile buluştuğunda kabuğunun etrafında müsilaj oluşturma ve yağ/su emülsiyonlarını stabilize etme özelliklerini taşır. Bu özellikleri ile besin endüstrisinde birçok alanda kullanılma potansiyeli yüksek bir hammadde olarak değerlendirilebilir. Bu derlemede, Chia tohumunun beslenme yönünden etkileri, işlevsel bileşenleri ve ulusal ve uluslararası besin endüstrisinde kullanım alanları ile ilgili çalışmalar derlenmiştir.

Anahtar kelimeler: Chia tohumu, n-3, diyet posasl, diyabet, obezite

\begin{abstract}
Chia seed, which has been popular in recent years, is a food rich in functional food ingredients such as dietary fiber, n-3 fatty acids, protein and antioxidants, of which health benefits are proven by scientific studies. $100 \mathrm{~g}$ of Chia is composed of 16 - 20 g protein, 30 - $38 \mathrm{~g}$ fat, 18 - $20 \mathrm{~g} \mathrm{n}-3$ fatty acids and 34 - $40 \mathrm{~g}$ total dietary fiber. In recent years, healthy food consumption trends are focused on the foods enriched with dietary fiber, n-3 fatty acids and antioxidants. Chia seed is defined as "superfood"; because it contains functional food ingredients which can be effective on preventing the illnesses, which are commonly seen in recent years, such as cancer, diabetes, obesity and cardiovascular diseases. Besides the effects on health and nutrition, Chia seed has the properties of forming a mucilage around its coat when in contact with water and stabilizing oil in water emulsions. Due to these properties it can be evaluated as a raw material having a high potential to be used in different purposes in the food industry. In this review, the studies about the health and nutrition effects of Chia seed, its functional ingredients and the usage areas in national and international food industries are summarized.
\end{abstract}

Keywords: Chia seed, n-3, dietary fiber, diabetes, obesity

1. İstanbul Teknik Üniversitesi, Kimya - Metalurji Mühendisliği Fakültesi, Gıda Mühendisliği Bölümü, İstanbul, Türkiye (ㄱ) https://orcid.org/0000-0001-9266-6122
2. ̇letişim/Correspondence: İstanbul Teknik Üniversitesi, Kimya - Metalurji Mühendisliği Fakültesi, Gıda Mühendisliği Bölümü, İstanbul, Türkiye • E-posta: sahinnes@itu.edu.tr

(ㄱ https://orcid.org/0000-0002-4179-1932 


\section{GíRiş}

Son yıllarda, ülkemizde ve Dünyada, bireylerde sağlıklı yaşam için sağlıklı beslenme bilincinin artmasına bağlı olarak, sağlık üzerine yararlı etkileri bilimsel çalışmalarca kanıtlanmış işlevsel besinleri tüketmeye olan eğilim artmıştır. Gelişmiş ülkelerde görülen ölümcül hastalıkların başında kanser, kardiyovasküler rahatsızlıklar, obezite ve diyabet gelmektedir. Bu hastalıkların görülme sıklıklarının artması insanların diyet posası, n-3 yağ asidi, antioksidanlar ve proteinler gibi işlevsel besin bileşenlerince zengin besinleri tüketmeye olan eğilimini arttırmıştır.

Günümüzde popülaritesi gittikçe artmakta olan ve "süper besin" olarak isimlendirilen Chia tohumunun ilk kullanımları, M.Ö. 3500 yıllarına dayanmaktadır. Eski Aztek ve Amerikan toplumları tarafindan enerji sağlamak, hayvanların dayanıklılığını arttırmak ve ilaç yapımında kullanmak amaçlarıyla tüketildiği rapor edilmiştir (1). Chia tohumu yaklaşık olarak \%16.5 protein, \%30 yağ, \%18 n-3 yağ asidi, \%35 toplam diyet posası içerir (2). İşlevsel besin bileşenlerini yüksek oranda sağlaması nedeniyle Chia tohumunun kardiyovasküler hastalıklar, diyabet, kanser ve obezite gibi kronik hastalıklardan korunmaya önemli ölçüde yardımcı olmada etkili olduğu belirtilmiştir (3). Chia tohumunun n-3 içeriği kinoa tohumundan, protein içeriği pirinç, mısır, buğday ve yulaftan fazla bulunmuştur (4).

Chia tohumunun içerdiği işlevsel besin bileşenlerinden birisi olan diyet posası, iştahı kontrol altına alma (5), kardiyovasküler hastalık riskini azaltma (6,7), kanserli hücre oranını düşürme (6) özellikleri ile bilinmektedir. Amerikan Diyetisyenler Birliği, yetişkin kadınlar için günde $25 \mathrm{~g}$, yetişkin erkekler için günde $38 \mathrm{~g}$ diyet posası alımını önermekte, günde 10-29 g diyet posası alımı ile diyabetin kontrol altında tutabileceğini vurgulamaktadır. Diğer bir işlevsel besin bileşeni olan n-3 yağ asitlerinin bağışıklık sistemi, kanser, şizofreni, beyin ve göz gelişimi, kardiyovasküler hastalıklar ve obezite üzerine yararlı etkileri bulunmaktadır (8). Chia tohumu (1 g) başta klorojenik asit, kafeik asit, kuersetin ve kamferol olmak üzere, antioksidan özelliğe sahip toplam 0.75 $\mathrm{g}$ fenolik bileşen içermektedir. Chia tohumunun içerdiği antioksidanların lipit peroksidasyonunu C vitamininden daha iyi baskıladığı bilinmektedir (9). Antioksidanlar, yaşlanma belirtileri (10), kanser, kalp rahatsızlıkları, Alzheimer hastalığı (11-12), beyin nöronları dejenerasyonu, katarakt (13) hastalıkları üzerinde etkileri bilimsel çalışmalara konu olmuş işlevsel besin bileşenleridir. Chia tohumunun protein bileşimi dokuzu elzem aminoasit olmak üzere, on sekiz çeşit aminoasit içermektedir (1). Protein, insan vücudunun temel yapı taşı olmakla birlikte, vücut ağırlığının kontrol altına alınmasında etkili bir besin bileşenidir (7).

Chia tohumu kendi ağırlığının 27 katı kadar su tutma ve su ile karşılaştığında hızlıca müsilaj oluşturma özelliğine sahiptir (2). Bu özellik Chia tohumunu, besin sanayinde kullanılan ticari kıvam arttırıcıların yerine geçebilecek potansiyel doğal bir kıvam arttırıcı olarak ön plana çıkarmaktadır.

$\mathrm{Bu}$ derleme yazıda, Chia tohumunun beslenme yönünden etkileri, işlevsel bileşenleri ve ulusal ve uluslararası besin endüstrisinde kullanım alanları ile ilgili çalışmaların değerlendirilmesi amaçlanmıştır.

\section{Chia Tohumu (Salvia hispanica L.)}

Chia tohumu, Lamiaceae ailesine bağll, nanegillerden olan Chia bitkisinin tohumudur. Chia bitkisi, $1 \mathrm{~m}$ yüksekliğinde, oval yaprakları, mor renkli çiçekleri, $40 \mathrm{~mm}$ uzunluğunda yaprak sapı olan bir bitkidir. Yaprakları 80-100 mm uzunluğunda ve 40-60 mm genişliğindedir. Chia tohumu, Şekil 1'de görüldüğü gibi, siyah, gri ve beyaz renklerde olabilen, $1.87 \pm 0.1$ $\mathrm{mm}$ uzunluğunda, $1.21 \pm 0.08 \mathrm{~mm}$ genişliğinde ve $0.88 \pm 0.04 \mathrm{~mm}$ kalınlığında oval şekilli tohumlardır (2).

Chia bitkisinin MÖ 1500-900 yılları arasında Meksika'dayetiştirildiğinedairkanıtlarbulunmaktadır (2). Chia bitkisinin, tarihte, sicak iklimlerden, 2500 $\mathrm{m}$ rakımda çok soğuk iklimlere kadar olan geniş bir 
coğrafyada yetiştirildiğinin bilinmesine karşıllk, en uygun yetiştirilme koşulları ılıman ekvator iklimidir. Günümüzde ticari olarak en çok Arjantin, Ekvator, Peru, Paraguay, Avusturalya, Meksika, Nikaragua, Guatemala ve Bolivya'da yetiştirilmektedir. Chia bitkisi killi yumuşak topraklarda daha yüksek verimle yetişmektedir. Yetiştirildiği toprağın düşük oranda azot içermesi verimi arttırmaktadır (2).

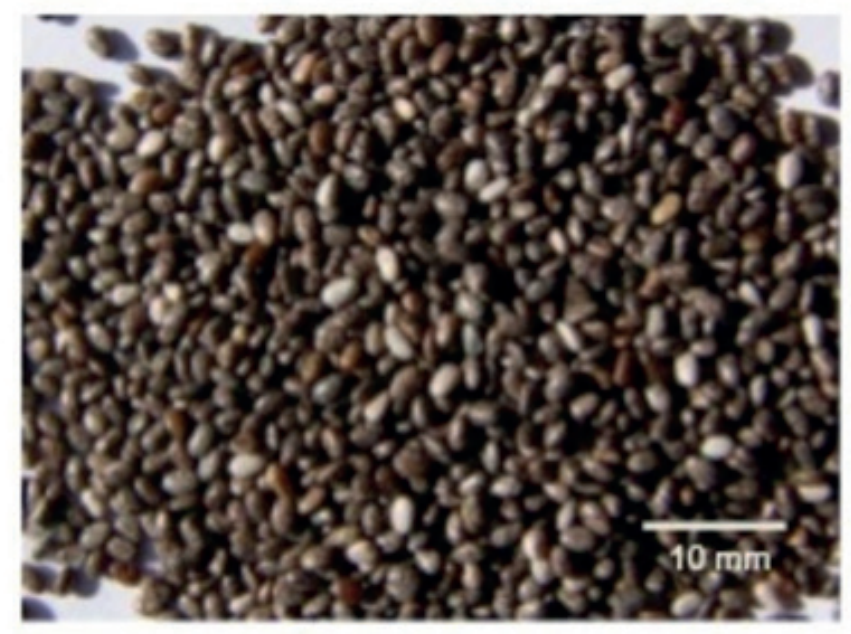

Şekil 1. Chia tohumu (2)

\section{Chia Tohumunun Bileşimi}

Chia tohumunun, yağ, protein, diyet posası ve n-3 içeriği birçok tohum çeşidinden yüksek olan bir besindir. Tablo 1'de farklı araştırmalara göre belirlenen Chia tohumunun bileşimi verilmiştir $(2,14-$ 15).

Chia tohumu, 100 g’ında 34-40 g diyet posası içermekte olup, yetişkin bir insanın günlük alması gereken diyet posasını karşılama katkısı yüksektir. $\mathrm{Bu}$ nedenle, Amerikan Diyetisyenler Birliği Chia tohumunun kardiyovasküler hastalıklar, diyabet ve obeziteyi önlemede etkili olduğunu bildirmiştir.
Chia tohumunun diyet posası fraksiyonu \%53-56 oranında metabolizmada kullanılabilen çözünür diyet posasından oluşmaktadır. Besin endüstrisinde ticari bir emülgatör olarak kullanılan mısır gluteninin emülsifiye etme aktivitesi \%49.3, oluşan emülsiyonun stabilitesi \%39.7 iken, Chia tohumu diyet posasının emülsifiye etme aktivitesi \%53.3, oluşan emülsiyonun stabilitesi \%94.8'dir. Antioksidan aktivitesi ise şarap, kahve, çay ve portakal suyundan daha yüksektir (16).

Chia tohumunun 100 g'ında toplam 30-38 g yağ bulunmaktadır. Yağın bileşimi Tablo 2'de verilmiştir. Chia tohumu yağının 100 g’ı 60-62 g elzem yağ asitlerinden olan a-linolenik asit (C18:3n-3) n-3 yağ asidini içerir. n-3 yağ asitlerinin, obezite, hipertansiyon, diyabet, kardiyovasküler hastalıklar, kanser gibi hastalıkları önlemede önemli role sahiptir $(17,18)$. Alfa-linolenik asit vücutta metabolize olarak diğer n-3 yağ asitlerinden olan eikosapentaenoik asit (EPA) ve dokosaheksaenoik aside (DHA) dönüşmektedir. İnsan beyninde yüksek oranlarda bulunan n-3 yağ asidi DHA'dır. DHA insan beynindeki yağ asitlerinin \%40'ını oluştururken, EPA \%1'den az bir kısmını oluşturmaktadır (17). EPA ve DHA beyin hücrelerinin metabolizmalarını düzenlemek, beyin hücrelerinin elastikiyetlerini module etmek, beyindeki hücre zarlarının geçirgenliğini arttırmak gibi etkileri başta olmak üzere, birçok klinik etkisi kanıtlanmış yağ asitleridir (18-20). Altmış beş yaş üzerindeki bireyler üzerinde yapılan klinik bir çalışmada, yüksek miktarda n-3 yağ asidi alımının demans ve Alzeimer hastalık riskini azalttığı gözlenmiştir (21).

Chia tohumu, yetiştirildiği iklim ve toprak şartlarına bağlı olarak değişmek üzere, \%15-23 oranında protein içerir. Bazı tahılların protein içerikleri ise yulafta $\% 16$, buğdayda \%14, arpada \%12.5, misirda \%9, pirinçte \%6'dır (2). Chia tohumu, alerjen bir protein

Tablo 1. Chia tohumunun bileşimi (100 g)

\begin{tabular}{lccccc}
\hline $\begin{array}{l}\text { Enerji } \\
\text { (kkal) }\end{array}$ & $\begin{array}{c}\text { Protein } \\
\text { (\%) }\end{array}$ & $\begin{array}{c}\text { Yağ } \\
\mathbf{( \% )}\end{array}$ & $\begin{array}{c}\text { Toplam diyet posası } \\
\text { (\%) }\end{array}$ & $\begin{array}{c}\text { n-3 yağ asitleri } \\
\text { (\%) }\end{array}$ & Kaynak \\
\hline 486 & 15.5 & 30.7 & 34.4 & 17.8 & 2 \\
477.6 & 19.6 & 29.0 & 38.9 & 17.8 & 14 \\
431 & 18.3 & 32.4 & 22.2 & 20.1 & 15 \\
\hline
\end{tabular}


olan gluten içermediği için çölyak hastalarının diyetleri için de uygun bir besindir. Chia tohumu unu kullanılarak yapılan glutensiz ekmekler duyusal testlerde kabul görmektedir (22). Chia tohumu diğer tahıllarla kıyaslandığında daha yüksek miktarda vitamin ve mineral içermektedir. Sütten 6 kat daha fazla kalsiyum, 11 kat daha fazla fosfor, 4 kat daha fazla potasyum içerir. Demir içeriği ispanaktan fazladır. Kalsiyum, fosfor ve potasyum içeriği buğday, pirinç, yulaf ve mısırdan daha yüksektir (2).

Tablo 2. Chia tohumu yağının yağ asidi bileşimi (14)

\begin{tabular}{lc}
\hline Yağ asitleri & Yağda, \% \\
\hline Miristik asit (C14:0) & 0.05 \\
Palmitik asit (C16:0) & 7.6 \\
Palmitoleik asit (C16:1) & 0.01 \\
Stearik asit (C18:0) & 3.4 \\
Oleik asit (C18:1) & 7.3 \\
Linoleik asit (C18:2) & 19.8 \\
a linolenik asit (C18:3, n-3) & 61.5 \\
\hline
\end{tabular}

Chia tohumu antioksidan kapasitesi yüksek fenolik bileşenler içermektedir. $\mathrm{Bu}$ fenolik bileşenlerin önemli bir bölümünü tokoferoller oluşturmaktadır. Chia tohumunun tokoferol miktarı (238-427 mg/ $\mathrm{kg}$ ), yer fistığının tokoferol miktarı ile benzerlik gösterirken (398.6 mg/kg), keten tohumunun (588.5 $\mathrm{mg} / \mathrm{kg})$, ayçiçek tohumunun $(634.4 \mathrm{mg} / \mathrm{kg})$ ve soya fasulyesinin (1797.6 mg/kg) tokoferol miktarlarından düşüktür (2). Chia tohumundaki fenolik bileşenlerinin büyük çoğunluğunu klorojenik asit $\left(7.1 \times 10^{-4} \mathrm{~mol} /\right.$ $\mathrm{kg})$, kafeik asit $\left(6.6 \times 10^{-3} \mathrm{~mol} / \mathrm{kg}\right)$, kuersetin $\left(2 \times 10^{-3}\right.$ $\mathrm{mol} / \mathrm{kg})$ ve kaemferol oluşturmaktadır $\left(1.1 \times 10^{-3} \mathrm{~mol} /\right.$ $\mathrm{kg}$ ) (2). Bu bileşenlerin antioksidan özelliklerinin $\mathrm{C}$ vitamini, ferulik asit ve $\mathrm{E}$ vitamininin antioksidan özelliklerinden daha güçlü olduğu rapor edilmiştir (2).

\section{Chia Tohumu ve Bileşenlerinin Besinlerdeki Uygulamaları}

\section{İşlevsel hammadde olarak kullanımı}

Chia tohumu, zengin içeriği ve sağlık üzerine yararlı etkilerinin yanında, besin sanayiinde kıvam arttırıcı, emülgatör, stabilizatör olarak kullanılabilecek birçok özelliğe sahip bir besindir. Yüksek miktarda içerdiği Chia gamı ve müsilaj oluşturma özelliği sayesinde, ticari kıvam arttırıcıların yerine kullanılabilme potansiyeli yüksektir (23).

Chia tohumu kendi ağırlığının 27 katı kadar su tutma özelliğine sahip bir besindir (2). Camsı geçiş sıcaklığı $\left(\mathrm{T}_{\mathrm{g}}\right.$ ), jel yapıdaki polimer zinciri konusunda bilgi veren bir parametredir. Yüksek $\mathrm{T}_{\mathrm{g}}$, daha sıkı bir polimer yapı, daha uzun polimer zincirlerinin göstergesidir. Chia tohumu ve Chia tohumu ununun oluşturdukları jellerin kuvvetleri, camsı geçiş sıcaklıkları göz önüne alınarak kıyaslandığında, Chia tohumu ununun daha zayıf bir jel oluşturduğu gözlenmiştir (14). Chia tohumunun oluşturduğu jel için $\mathrm{T}_{g}$ değeri $44.6^{\circ} \mathrm{C}$ iken, ticari bir kıvam arttırıcı olarak kullanılan pektinin oluşturduğu jelin $\mathrm{T}_{\mathrm{g}}$ değeri $48^{\circ} \mathrm{C}$ olarak gözlenmiştir $(14,23)$. Bu benzerlik, Chia tohumunun, ticari bir kıvam arttırıcı olarak kullanılabilme potansiyelini göstermektedir. Chia tohumunun oluşturduğu jelin, ticari kıvam arttırıcı olarak kullanılan guar gum, aljinat ve jelatinle kıyaslandığında daha iyi su tutma, yağ tutma ve emülsiyon stabilizasyonu sağlama özelliklerine sahip olduğu belirtilmektedir (24).

Diğer kıvam arttırıcılardan farklı olarak beslenme açısından diğer işlevsel bileşenlere de sahip olması nedeniyle, Chia tohumunun ticari kıvam arttırıcıların yerini alabileceği veya belli oranlarda ikame edilebileceği öngörülmektedir.

Chia tohumu müsilajı yağ/su emülsiyonlarında stabilizatör olarak kullanılma potansiyeli yüksek bir hammaddedir. Ayçiçek lesitini ve Chia tohumu müsilajı farklı düzeylerde birlikte kullanıldığında, Chia tohumu müsilajının yağ parçacıklarının mobilitesini azaltarak, emülsiyon stabilizasyonuna katkı sağladığı gözlenmiştir (25). Chia tohumu, yüksek miktarda içerdiği diyet posasından gam elde edilebilen bir tohum çeşididir. Elde edilen bu gam, yüksek su ve yağ tutma kapasitelerine sahiptir (26). Chia unu, yenilebilir film yapımında kullanılma potansiyeli yüksek bir hammaddedir. Yapılan çalışmalarda, Chia unu ile yapılan yenilebilir filmlerin düşük çözünürlük gösterdiği, yüksek su buharı tutma kapasitesine sahip olduğu ve UV radyasyona karşı dayanıklı olduğu 
rapor edilmiştir (27).

\section{Besin formülasyonlarında besin değerinin arttırılmasında kullanımı}

Chia tohumu ve Chia tohumundan elde edilen ürünler, besin sanayinde işlevsel hammadde olabilmelerinin yanında, formülasyonlarına uyarladıkları besinlerin besin değerini de arttırırlar. Chia tohumu, bu bağlamda, genelde unlu mamüller ve süt ürünleri formülasyonlarına uyarlamaya çalışılmış ve olumlu sonuçlar alınmıştır (15,22,28-30).

Chia tohumu ülkemizde, günlük diyetin bir parçası olarak, beslenmeye katkı sağlamak amacıyla doğrudan tüketildiği gibi, besin endüstrisinde de kullanılmaya başlamıştır. Bunlardan ilki ekmeğin besin kalitesini arttırmak amacıyla ekmek yapımında kullanımıdır. Ülkemiz dışında, Chia tohumu daha yaygın kullanım alanı bulmaktadır. Sporcu içeceklerinde, barlarda, unlu mamüllerde doğrudan besin formülasyonunda bulunmaktadır. Bu ürünler Chia tohumu eklenmesi ile yüksek protein, diyet posası, n-3 içeriğiyle "işlevsel besin" sinıfina girmektedir. Chia tohumundan elde edilen bileşenler ticari olarak uluslararası pazarda da yerini bulmuştur. n-3 yağ asidi (\%60) içeren Chia tohumu yağı "n-3 kaynağı" etiketiyle, chia tohumu proteini "protein kaynağı" etiketiyle satılmaktadır (31-33).

Chia tohumunun besin formülasyonlarda kullanım potansiyeli çeşitli bilimsel çalışmalarla desteklemiştir (14-15,22-30,34). Chia tohumu unu, keten tohumu unu ve buğday unu ekmek yapımında bir arada kullanıldığında, üretilen ekmeklerin kontrol grubu ekmeklerine göre daha yüksek protein, doymamış yağ asidi, diyet posası ve folik asitiçerdiği, duyusal testlerde kabul gördüğü gözlenmiştir (28). Daha yüksek besin değerine sahip ekmek geliştirmek amacıyla, bütün Chia tohumu unu, yarı yağlı Chia tohumu unu ve düşük yağlı Chia tohumu unu ekmek yapımında test edilmiştir.Üretilen ekmeklerin protein, yağ, mineralve diyet posası oranlarının kontrol grubu ekmeklerinden daha yüksek olduğu, duyusal testlerde kabul gördüğü, hamur aşamasında herhangi bir işleme zorluğunun gözlenmediği, nişastanın termal özelliklerinin değişmediği, amilopektin retrogradasyonunun azaldığı ve bayatlamanın geciktiği rapor edilmiştir (28). n-3 yağ asitlerinden zenginleştirilmiş ekmek üretimi için bütün Chia tohumu unu ve gluten farklı düzeylerde bir arada kullanıldığında, ekmek hacmi, ekmek içi gözenek yapısı, dilim hacmi ve ekmek içi rengi özellikleri, \%10 Chia tohumu unu ve \%2 gluten içeren formülasyon kullanıldığında elde edilmiştir. $\mathrm{Bu}$ formülasyon, duyusal testlerde kabul görürken, kontrol ekmeklerine göre \%26 daha fazla yağ, \%19 daha fazla protein, kontrole göre 24 kat artmış n-3 yağ asidi miktarı içermektedir. n-3 yağ asitlerinden zenginleştirilmiş ekmek üretimi için bütün Chia tohumu unu kullanılan bu çalışmada, n-6/n-3 oranının 1.45 olduğu gözlenmiştir (29). Chia tohumu unu, gluten içermediği için çölyak hastalarının tüketimine uygun, besleyici değeri yüksek alternatif bir besindir. Ekmek üzerine yapılan bir çalışmada pirinç unu, Chia tohumu unu ile ikame edildiğinde, müşteri beğenisinin değişmediği, içyapının daha iyi olduğu ve besin değerlerinin arttığı gözlenmiştir (22). Ekmeğin yanı sıra kurabiye gibi unlu mamullerde de Chia tohumu unu kullanımı uygun bir hammaddedir. Yulaf ununun Chia tohumu unu ile ikame edilerek yapıldığı kurabiyelerde besin kalitesinin ve fiziksel parametrelerin iyileştiği, ancak kurabiye çapının düşerken yüksekliğin arttığı gözlenmiştir (34).

Chia tohumu unu kullanılarak ekmek yapılan çalışmalarda, Chia tohumu unu kullanımının ekmek yapım aşamalarını zorlaştırmadığı gözlenmiştir. Ekmek hamuruna Chia tohumu müsilajı ilave etmek, hamur stabilitesini arttırmıştır (30).

Chia müsilaj jeli, ağızdaki yağsı yapısından dolayı, yağlı yiyeceklerde yağ miktarını azaltmak üzere kullanılma potansiyeli yüksek bir hammaddedir. Bu özelliği ile diyet ürünlerin formülasyonlarında kullanımı uygun bir bileşendir. Daha az yağ içeren ekmek formülasyonu geliştirmek için yapılan çalışmalarda, Chia tohumu veya unundan oluşan müsilajın kullanılabileceği öngörülerek, endüstriyel kullanıma uygun iki farklı formülasyon geliştirilmiştir. Duyusal testlerde kabul gören bu formülasyonlar, \%7.8 Chia tohumu unu + \%0.9 yağ içeren ve \%11 Chia tohumu 
unu +\%1 yağ içeren formülasyonlardır. Her iki formülayonda da doymamış yağ asidi düzeyi kontrol ekmeklerine kıyasla \%200'den fazla artmıştır (15). Kek formülasyonunda yağ oranını düşürmek için yapılan çalışmada \%25 Chia müsilaj jeli içeren formülasyonun kek hacmi, simetrisi, gözenek yapısı, nem miktarı ve su aktivitesi değerleri değişmezken, bu formülün duyusal testlerde kabul gördüğü belirlenmiştir (35).

\section{Chia tohumunun hayvan yemlerinde kullanımı}

Chia tohumu, hayvansal besinlerin kalitesini arttırmak için hayvan yemi olarak da kullanım alanı bulmuştur. Aztek’ler tarafından yüksek enerji sağlaması için atlara yedirilen Chia tohumu, günümüzde yumurta ve et kalitesini arttırmak için yapılan çalışmalara konu olmuştur. Yumurtaların n-3 yağ asidi içeriğine, tavuk yemlerinde Chia tohumu yağı, keten tohumu yağı ve balık yağının etkisini saptamak için yapılan bir çalışmada, Chia tohumu yağı tüketen tavukların yumurtalarının n-3 yağ asidi miktarlarının diğer yağları tüketen tavukların yumurtalarına oranla \%100-120 oranında arttığı gözlenmiştir. Diyetlerindeki bu değişimden tavukların olumsuz etkilenmediği belirtilmiştir (36). Tavşan etindeki yağ profilini değiştirmek için yapılan çalışmada, diyetlerine \%15 Chia tohumu ilave edilen tavşanların etlerinde, doymuş yağ oranı \%4.55'den \%1.03'e düşmüştür (37). Domuz etinin duyusal parametrelerini ve yağ asidi profilini değiştirmek için yapılan çalışmalarda, diyetlerine \%20 oranında Chia tohumu ilave edilmiş domuzların etlerindeki toplam yağ asitleri içinde palmitik asidin \%32'den \%25'e, stearik asidin \%15'den \%11'e, araşidonik asidin \%0.23'den \%0.19'a düştüğü, a-linolenik asidin ise \%0.09'dan \%0.39'a çıktığ belirtilmiştir. Diyetlere Chia tohumu ilave edilmesi domuzları olumsuz etkilemezken, duyusal testlerde domuz etinin aroma ve tat özelliklerinin müşteriler tarafından daha fazla beğenildiği belirtilmiştir (4).

\section{SONUÇ VE ÖNERILLER}

Chia tohumu son yllarda ülkemizde ve Dünyada popülaritesi artmakta olan, birden fazla yararlı sağlık etkilerini bir arada içeren bir besindir. Ülkemizde, yüksek oranda diyet posası içermesi ve bu sayede açlık hissini azaltması nedeniyle vücut ağırlığı kontrolünü hedefleyen diyetlerde önem kazanmıştır. Chia tohumu, balık ve balık ürünleri alerjisi olan kişiler tarafından tüketilmeye uygun alternatif bir n-3 yağ asidi kaynağıdır. Chia tohumunun sağlık üzerine etkileri konusunda epidemiyolojik ve deneysel çalışmalara gereksinim duyulmaktadır.

Günümüzde ticari olarak kıvam arttırıcı ve stabilizatör olarak kullanılan hammaddelerin besleyici özellikleri bulunmamaktadır. Yapılan çalışmalar, besleyici özelliklerinin yanı sıra, Chia tohumunun, kıvam arttırıcı ve stabilizatör olarak kullanılabileceğini göstermektedir. Chia tohumu, özellikle unlu mamuller gibi Türk toplumunun sıllıkla tükettiği besinlerde, mevcut hammaddelerle ikame edilerek değerlendirildiğinde olumlu sonuçlar alınmıştır. Tüm özellikleri ile değerlendirildiğinde, Chia tohumu, besin sanayiinde işlevsel besinlerde geniş kullanım alanı bulma potansiyeli olan bir besindir. Gelecekte, Chia tohumu üzerine yapılan çalışmaların arttırılması, besin sanayiinde işlevsel hammadde olarak kullanım alanlarının yaygınlaştırılması beklenmektedir.

Çıkar çatışması - Conflict of interest: Yazarlar çıkar çatışması olmadığını beyan ederler. - The authors declare that they have no conflict of interest.

\section{KAYNAKLAR}

1. Ayerza R, Coates W. Chia seeds and the Columbus concept. Wild-type food in health promotion and disease prevention, edited by Humana Press Inc, Totowa, NJ; 2008. p. 377-392.

2. Munoz LA, Cobos A, Daz O, Aguliera JM. Chia seed (Salvia hispanica): An ancient grain and a new functional food. Food Rev Int 2013;29:394-408.

3. Position of American Dietetic Association. Health implications of dietary fiber. J Am Diet Assoc 2008;108(10):1716 - 1731.

4. Ayerza R. Chia as a new source of omega-3 fatty acids. Wild-Type Food in Health Promotion and Disease Prevention, edited by F. De Meester and R. R. Watson Humana Press Inc., Totowa, NJ; 2009. p. 179-194.

5. Kristensen M, Jensen MG. Dietary fibers in the regulation of appetite and food intake, Importance of viscosity. Appetite 2011;56:65-70. 
6. Kim Y, Je Y. Dietary fibre intake and mortality from cardiovascular diseases and all cancers. Arch Cardiovasc Dis 2016;109:39-54.

7. Belski R. Fiber, protein and lupin-enriched foods: Role for improving cardiovascular health. Adv Food Nutr Res 2012;66:147-215.

8. Fernandez L, Laiglesia LM, Huerta AE, Martinez JA, Aliaga MJM. Omega-3 fatty acids and adipose tissue function in obesity and metabolic syndrome. Prostaglandins 2015;121(Pt A):24-41.

9. Caudillo ER, Tecante A, Lopez MAV. Dietary fiber content and antioxidant activity of phenolic compounds in Mexican chia seeds. Food Chem 2008;107(2):656-663.

10. Finkel T. Oxidants, oxidative stress and biology of aging. Nature 2000; 408(6809):239-247.

11. Ames BN. Dietary carcinogens and anticarcinogens: Oxygen radicals and degenerative diseases. Science 1983;221(4617):1256-1264.

12. Smith MA, Perry G, Richey PL, Sayre LM, Anderson VE, Beal MF, Kowall N. Oxidative damage in Alzheimer's. Nature 1996;382(6587):120-121.

13. Auroma O. Free radicals, oxidative stress and antioxidants in human health and disease. J Am Oil Chem Soc 1998;75(2):199-212.

14. Özbek T. Chia seed added strawberry marmalade with no added sugar, İTÜ Fen Bilimleri Enstitüsü Yüksek Lisans Tezi, 2016.

15. Coelho MS, Mellado M. Chemical characterization of chia for use in food products. J Food Nutr Res 2014;2(5):263269.

16. Alfredo VO, Gabriel RR, Luis CG, David BA. Physicochemical properties of a fibrous fraction from chia (Salvia hispanica L.). LWT Food Sci Technol 2009;42(1):168-173.

17. Bos DJ, Montfort SJI, Oranje B, Durston S, Smeets PAM. Effects of omega - 3 PUFAs on human brain morphology and function. Eur Neuropsychopharm 2016;26(3):546561.

18. Dunbar BS, Bosire RV, Deckelbaum RJ. Omega 3 and omega 6 fatty acids in human health: An African perspective. Mol Cel Endocrinol 2014;398(1-2):69-77.

19. Gorjão R, Azevedo-Martins AK, Rodrigues HG, Abdulkader F, Arcisio-Miranda M, Procopio J. Comparative effects of DHA and EPA on cell function. Pharmacol Ther 2009;122(1):56-64.

20. Luchtman DW, Song C. Cognitive enhancement by omega-3 fatty acids from childhood to old-age. Findings from animal and clinical studies. Neuropharmacology 2013;64:550-565.

21. Wu S, Ding Y, Wu F, Li R, Hou J, Mao P. Omega-3 fatty acids intake and risks of dementia and Alzheimer' $\mathrm{s}$ disease. Neurosci Biobehav Rev 2015;48:1-9.
22. Steffolani E, Hera EL, Perez G, Gomez M. Effect of chia (Salvia hispanica) addition on the quality of gluten free bread. J Food Quality 2014;37(5):309-317.

23. Karaki N, Aljawish A, Muniglia L, Humeau C, Jasniewski J. Physicochemical characterization of pectin grafted with exogenous phenols. Food Hydrocoll 2016;60:486493.

24. Coorey R, Grant A, Jayasena V. Effects of Chia Flour incorporation on the nutritive quality and consumer acceptance of chips. J Food Res 2012;1(4):85-95.

25. Guiotto EN, Capitani MI, Nolasco SM, Tomas MC. Stability of oil in water emulsions with sunflower and chia by products J Am Oil Chem Soc 2016;93(1):133-143.

26. Campos MRS, Solis N, Rubio GR, Guerrero LC, Ancora DB. Chemical and functional properties of chia seed gum. Hindawi J Food Sci 2014, Article ID 241053, p.5.

27. Dick M, Costa TMH, Gomaa A, Subirade M, Rios A, Flores SH. Edible film production from chia seed mucilage: Effect of glycerolconcentration on its physicochemical and mechanical properties. Carbohydr Polym 2015;130:198-205.

28. Iglesias E, Haros M. Evaluation of performance of dough and bread incorporating chia. Eur Food Res Technol 2013;237:865-874.

29. Pizarro PL, Almeida EL, Coelho AS, Samman NC, Hubinger MD, Chang YK. Functional bread with n-3 alpha linolenic acid from whole chia flour. J Food Sci Technol 2015;52(7):4475-4482.

30. Zettel V, Kramer A, Hecker F, Hitzman B. Influence of gel from ground chia for wheat bread production. Eur Food Res Technol 2015;240:655-662.

31. Anon, MammaChia. Seed your soul. http://www. mammachia.com/ Erişim tarihi: 7 Nisan 2018.

32. Anon, Chia Star. https://www.chiastar.com. Erişim tarihi: 7 Nisan 2018.

33. Anon., Dragon Superfoods. http://dragonsuperfoods. com/de/, Erişim tarihi: 7 Nisan 2018.

34. Inglett GE, Chen D, Liu S. Physical properties of sugar cookies containing chia-oat composites. J Sci Food Agric 2014;94(15):3226-3233.

35. Felisberto MHF, Wahonik AL, Gomes CR, Clerici MTP, Chang YK, Steel CJ. Use of chia mucilage gel to reduce fat in pound cakes. J Food Sci Technol 2015;63(2):1049-1055.

36. Ayerza R. Chia as a new source of omega-3 fatty acids. Wild-Type Food in Health Promotion and Disease Prevention, edited by F. De Meester and R. R. Watson Humana Press Inc., Totowa, NJ; 2009. p.179-194.

37. Peiretti PB, Merineri G. Effects on growth performance, carcass characteristics, and the fat and meat fatty acid profile of rabbits fed diets with chia (Salvia hispanica L.) seed supplements. Meat Sci 2008;80:1116-1121. 